\title{
Effect of medium and light quality on pink pigment production of cyanobacteria Oscillatoria sp. BTCC/A0004
}

\author{
Karseno $^{1^{*}}$, Kazuo Harada ${ }^{2}$, and Kazumasa Hirata $^{2}$ \\ ${ }^{1)}$ Department of Agriculture Technology, Universitas Jenderal Soedirman \\ Kampus Karangwangkal, Purwokerto 53123 Indonesia \\ ${ }^{2)}$ Department of Applied and Environmental Biology, Graduate School of Pharmaceutical Sciences, \\ Osaka University, 1-6 Yamada-oka, Suita, Osaka 565-0871, Japan
}

\begin{abstract}
Cyanobacteria are well known as promising source of valuable chemicals for human usage. Especially, cyanobacteria in tropical area are very wide in diversity and they are potent producers of unique metabolites which exhibit interesting bioactivities. Oscilatoria sp. BTCC/A0004 produce pink pigments extracellularly (OsPP). The effects of various environmental factors on the production of cyanobacteria metabolites were well documented. In this research, the effect of medium and light quality on cell growth and OsPP production were investigated. In case, three different culture media, named No 18, C, and modified C media, in which nutrient compositions are different, and light quality (white, blue, green, pink) were tested. The highest cell growth and OsPP production were obtained in modified $\mathrm{C}$ medium. The nitrogen concentration in modified $\mathrm{C}$ medium is higher $(5 \mathrm{~g} / \mathrm{L})$ than in No 18 medium $(1.5 \mathrm{~g} / \mathrm{L})$ or $\mathrm{C}$ medium $(1$ $\mathrm{g} / \mathrm{L})$. In addition, cell growth and OsPP production were significantly stimulated by pink light radiation.
\end{abstract}

\section{Introduction}

Cyanobacteria are well known as promising source of valuable chemicals for human usage. They have been identified as one of the most attractive group of organisms for novel bioactive natural products [1]. Especially, cyanobacteria in tropical area are very wide in diversity and they are potent producers of unique metabolites which exhibit interesting bioactivities. However, most of them remain unexplored. In this study, we found tropical freshwater cyanobacterial strains, Oscillatoria sp. 
BTCC/A0004 produce pink pigments extracellularly (OsPP) and it was identified as phycoerytrin like pigment [2].

In previous study, OsPP exhibited physical properties similar to phycoerytrin (PE). PE has gained tremendous interest due to excellent spectroscopic properties. It has been extensively investigated and exploited commercially for usage such as for fluorescent dyes in bio-assay $[3,4]$. In this regards, OsPP might be substituted chemicals of PE. In addition, OsPP has potent growth inhibitory activity against green algae and cancer cells with function as photosensitizer. These results indicated that OsPP is promising substance for application in various fields.

In many papers, the effects of nutrient, light, $\mathrm{pH}$, temperature and co-cultivation with competitive organisms on the synthesis of cyanobacterial metabolites were well documented [5-7]. It was expected that those factors might stimulate the production of OsPP. Therefore, in this research the effects of nutrient and light quality on stimulate cell growth and OsPP production were investigated.

\section{Materials and methods}

\subsection{Algal cultivation condition}

Oscillatoria sp. was sub cultured in test tubes $(3 \mathrm{~cm}$ i.d. $\times 20 \mathrm{~cm})$ containing $50 \mathrm{ml}$ of modified $\mathrm{C}$ medium at $\mathrm{pH} 7.5$ with the following composition: (per liter) $5 \mathrm{~g} \mathrm{KNO}_{3}, 0.1 \mathrm{~g}$ $\mathrm{KH}_{2} \mathrm{PO}_{4}, 0.05 \mathrm{~g} \mathrm{MgSO}_{4} .7 \mathrm{H}_{2} \mathrm{O}, 0.005 \mathrm{~g} \mathrm{FeCl}_{2}, 2.86 \mathrm{mg} \mathrm{H}_{3} \mathrm{BO}_{3}, 1.81 \mathrm{mg} \mathrm{MnCl}{ }_{2} .4 \mathrm{H}_{2} \mathrm{O}, 0.22$ $\mathrm{mg} \mathrm{ZnSO}_{4} .7 \mathrm{H}_{2} \mathrm{O}, 0.018 \mathrm{mg}\left(\mathrm{NH}_{4}\right)_{6} \mathrm{Mo}_{7} \mathrm{O}_{24} \cdot 4 \mathrm{H}_{2} \mathrm{O}$, and $0.075 \mathrm{mg} \mathrm{CuSO} \mathrm{Cu}_{4} \cdot 5 \mathrm{H}_{2} \mathrm{O}$. The cells were cultivated with aeration $\left(10 \mathrm{ml} \mathrm{min}^{-1}, 1 \% \mathrm{CO} 2\right)$ at $25^{\circ} \mathrm{C}$ under $50 \mu \mathrm{mol}$ photons $\mathrm{m}^{-2} \mathrm{~s}^{-}$ ${ }^{1}$ of continuous illumination using white fluorescence lamps. For measurement of cell growth and pigment production, 4-day-old seed cultures of Oscillatoria sp. was transferred to fresh media and adjusted to 0.1 of $\mathrm{OD}_{680}$. Incubation conditions was the same as for seed cultures except for light intensity was $100 \mu \mathrm{mol}$ photons $\mathrm{m}^{-2} \mathrm{~s}^{-1}$.

\subsection{Effect of different media}

Three different culture media named C, modified C and No 18 media, in which nutrient compositions are different were tested (Table 1). The cultivation methods were same to basal cultivation condition.

Table 1. Chemical composition of three culture media $\left(\mathrm{L}^{-1}\right)$

\begin{tabular}{llll}
\hline \multicolumn{1}{c}{ Components } & No 18 & $\mathrm{C}$ & Modified C \\
\hline $\mathrm{NaCl}(\mathrm{mg})$ & 70 & - & - \\
$\mathrm{MgSO}_{4} 7 \mathrm{H}_{2} \mathrm{O}(\mathrm{mg})$ & 380 & 40 & 50 \\
$\mathrm{CaCl}_{2} \mathrm{H}_{2} \mathrm{O}(\mathrm{mg})$ & 106 & - & - \\
$\mathrm{Fe}_{2}\left(\mathrm{SO}_{4}\right)_{3} \mathrm{nH}_{2} \mathrm{O}(\mathrm{mg})$ & 10 & - & - \\
$\mathrm{Na}_{2} \mathrm{EDTA}_{2} \mathrm{H}_{2} \mathrm{O}(\mathrm{mg})$ & 27 & 1000 & - \\
$\mathrm{K}_{2} \mathrm{HPO}_{4}(\mathrm{mg})$ & 600 & - & 100 \\
\hline
\end{tabular}




\begin{tabular}{|c|c|c|c|}
\hline $\mathrm{H}_{3} \mathrm{BO}_{3}(\mathrm{mg})$ & 3 & - & 2.86 \\
\hline $\mathrm{MnSO}_{4} 4 \mathrm{H}_{2} \mathrm{O}(\mathrm{mg})$ & 2 & - & - \\
\hline $\mathrm{Na}_{2} \mathrm{MoO}_{4} 2 \mathrm{H}_{2} \mathrm{O}(\mathrm{mg})$ & 8 & 2.5 & - \\
\hline $\mathrm{ZnSO}_{4} 7 \mathrm{H}_{2} \mathrm{O}(\mathrm{mg})$ & 0.3 & 22 & 0.22 \\
\hline $\mathrm{CuSO}_{4} 5 \mathrm{H}_{2} \mathrm{O}(\mathrm{mg})$ & 0.08 & - & 0.075 \\
\hline $\mathrm{CoCl}_{2} 6 \mathrm{H}_{2} \mathrm{O}(\mathrm{mg})$ & 0.03 & 4 & - \\
\hline Titriplex III (g) & 0.07 & - & - \\
\hline $\mathrm{Ca}\left(\mathrm{NO}_{3}\right) 4 \mathrm{H}_{2} \mathrm{O}(\mathrm{mg})$ & - & 150 & - \\
\hline $\mathrm{KNO}_{3}(\mathrm{~g})$ & - & 0.1 & 5 \\
\hline $\mathrm{FeCl}_{3}(\mathrm{mg})$ & - & 196 & - \\
\hline $\mathrm{MnCl}_{2} 4 \mathrm{H}_{2} \mathrm{O}(\mathrm{mg})$ & - & 36 & 1.81 \\
\hline $\begin{array}{l}\text { Tris (hydroxymethyl) aminomethane } \\
\text { (mg) }\end{array}$ & - & 500 & - \\
\hline $\mathrm{NaH}_{2} \mathrm{PO}_{4} 2 \mathrm{H}_{2} \mathrm{O}(\mathrm{mg})$ & - & 50 & - \\
\hline Vitamin $B_{12}(\mu \mathrm{g})$ & - & 0.1 & - \\
\hline $\operatorname{Biotin}(\mu \mathrm{g})$ & - & 0.1 & - \\
\hline
\end{tabular}

\subsection{Effect of light quality}

To investigate the effects of light quality on cell growth and pink pigment production, the cells were cultivated in $100 \mathrm{ml}$ of modified $\mathrm{C}$ medium in Petri dishes $(6$ and $9 \mathrm{~cm}$ in depth and diameter, respectively). The dish was placed in a transparent cultivation box and illuminated continuously with $30 \mu \mathrm{mol}$ photons $\mathrm{m}^{-2} \mathrm{~s}^{-1}$ fluorescence light quality and aeration with $1 \% \mathrm{CO}_{2}$ in air, $25^{\circ} \mathrm{C}$. White, blue and green light were supplied with three 10 $\mathrm{W}$ fluorescence lamps (National, Japan). The pink light was supplied with three $10 \mathrm{~W}$ fluorescence lamps (NEC, Japan).

\section{Results}

\section{1. Effect of different culture media}

The effects of different media on cell growth and OsPP production were presented in Figure 1. The highest cell growth and OsPP production were obtained in modified $\mathrm{C}$ medium. Modified $\mathrm{C}$ medium contains more nitrogen $\left(\mathrm{KNO}_{3}\right)$ than two other media evaluated (Table 1). It is well known that nitrogen is an essential element required for the growth and synthesis of various metabolites [5]. This might be one of the reasons why cell 
growth and OsPP production in modified $\mathrm{C}$ medium were higher than those in the other media.
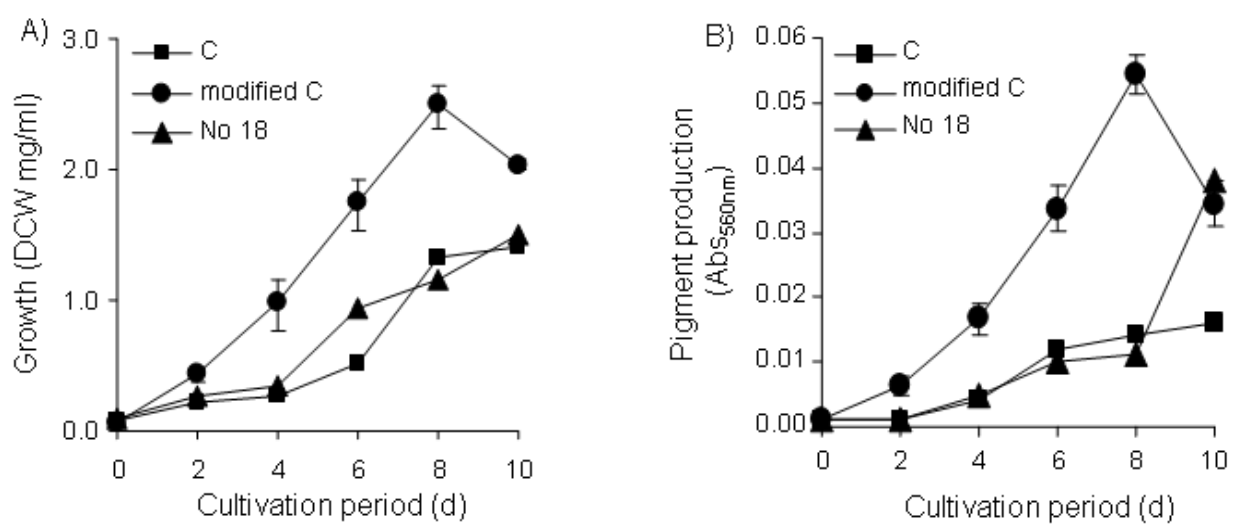

Fig. 1 Effect of different media on growth (A) and pigment production (B) of Oscillatoria sp. The cell was cultivated in various media in the light $\left(100 \mu \mathrm{mol}\right.$ photons $\left.\mathrm{m}^{-2} \mathrm{~s}^{-1}\right)$ and aeration of $1 \% \mathrm{CO}_{2}$ in air at $25^{\circ} \mathrm{C}$. DCW is dry cell weight. Values are the mean \pm SDs of three independent experiments.

\section{2. Effects of light quality}

Light is the primary energy source and play an important role in photosynthetic organisms including cyanobacteria. There are several reports that light quality as well as light intensity showed significant effects on growth and metabolism in cyanobacteria [8-11]. The effects of light quality on cell growth and OsPP production are shown in Figure 2. The cell growth and OsPP production were stimulated significantly by pink light irradiation.
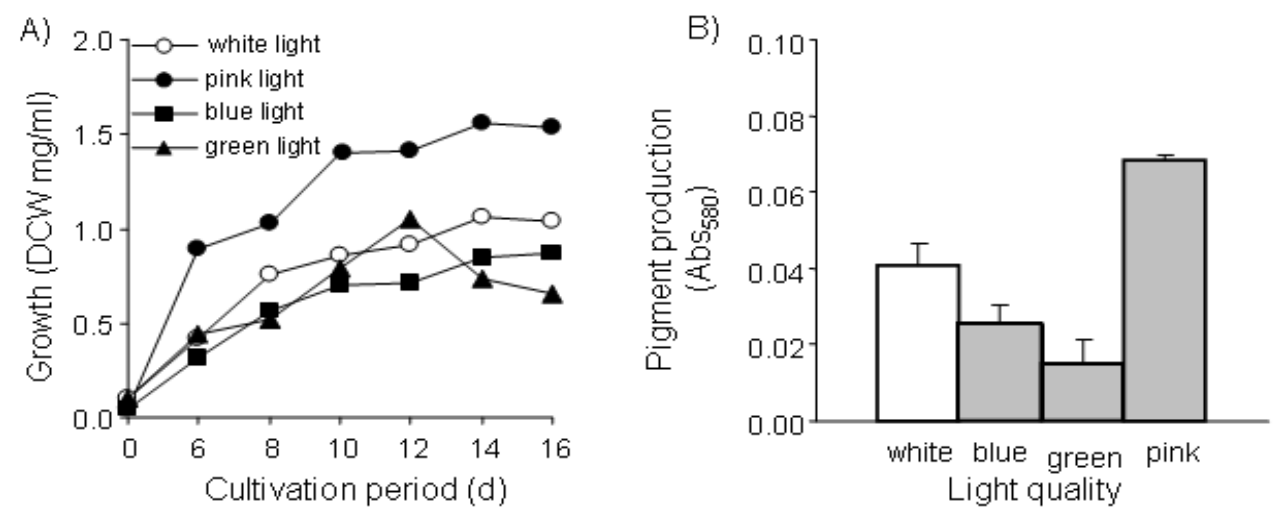

Fig. 2 Effects of light quality on growth (A) and pigment production (B) of Oscillatoria sp. Cells were cultivated under different wavelengths of light at $30 \mu \mathrm{mol}$ photons $\mathrm{m}^{-2} \mathrm{~s}^{-1}$. The production of OsPP in the medium was measured for 16-day-old Osillatoria sp. DCW is dry cell weight. Values are the mean \pm SDs of three independent experiments. 


\section{Discussion}

The effects of different media and light quality show significant effect on cell growth and OsPP production. Three different media $\mathrm{C}$, modified $\mathrm{C}$ and No 18 are known as culture media for cultivation of freshwater cyanobacteria. These media were also used for cultivation of several freshwater cyanobacteria. Under modified $\mathrm{C}$ medium, the pink pigment in culture media was clearly observed on 6-day-old Oscillatoria, which is correspond to the absorbance value $\left(\mathrm{Abs}_{560}\right)$ of 0.02 . On the other hand, the pigments from grown cells in No 18 and C media were observed on 10-day-old Oscillatoria, respectively.

The highest cell growth and OsPP production were obtained from grown cell in modified $\mathrm{C}$ medium (Fig. 1). The nitrogen concentration in modified $\mathrm{C}$ is higher $\left(5 \mathrm{~g} \mathrm{~L}^{-1}\right)$ than $\mathrm{C}$ medium $\left(0.1 \mathrm{~g} \mathrm{~L}^{-1}\right)$ or in No $18\left(0 \mathrm{~g} \mathrm{~L}^{-1}\right)$. The correlations between nitrogen concentration and cells growth as well as on the pigment production were well documented. Nitrogen is an essential major element required for the synthesis of primary and secondary amino acids, proteins, nucleic acids, coenzymes, chlorophyll and other accessory photosynthetic pigment such as phycobiliproteins in cyanobacteria [5]. It was reported that the concentration of $\mathrm{KNO}_{3}$ as nitrogen source was found to be an essential factor influencing the growth of Synechocystis sp. PCC 6701. In contrast, the growth and phycobiliproteins content in several cyanobacteria decreased during nitrogen starvation/limitation [12].

On the other hand, $\mathrm{K}_{2} \mathrm{HPO}_{4}$ as phosphorus source is also known as essential to algal growth because it was important roles in many cellular processes and it is maintaining $\mathrm{pH}$ of culture media by it buffering capacity [13]. Modified $\mathrm{C}$ medium containing phosphorus $\left(100 \mathrm{mg} \mathrm{L}^{-1}\right.$ as $\left.\mathrm{K}_{2} \mathrm{HPO}_{4}\right)$ might be appropriate concentration for growth of Oscillatoria strain. BG-11 medium supplemented with phosphorus $\left(10 \mathrm{mg} \mathrm{L^{-1 }}\right.$ as $\left.\mathrm{K}_{2} \mathrm{HPO}_{4}\right)$ was significantly stimulated the cell growth and phycoerythrin production of Nostochopsis lobatus [13]. In contrast, high levels of phosphorus in medium was inhibited the growth of Anabaena variabilis [14]. It was reported that nitrate $\left(\mathrm{KNO}_{3}\right)$ and phosphate $\left(\mathrm{K}_{2} \mathrm{HPO}_{4}\right)$ were identified as major factors of cell growth Synechocystis sp. PCC 6701 [12]. In this study, high cell growth and OsPP production obtained from modified $\mathrm{C}$ medium were agreed with these phenomena.

Light qualities as well light intensity play an important role on the cell growth and metabolite production in photosynthetic organisms, including cyanobacteria. For example, in Rhodella reticulate, the production of algal biomass is enhanced by about 5-6 times in response to increased light intensities from 18 to $215 \mu \mathrm{E} \mathrm{m} \mathrm{m}^{-2} \mathrm{~s}^{-1}$ under white, green or red light. At low light intensity, B-phycoerythrin content is preferentially enhanced to $27 \%$ under the influence of green light compared with red light [9]. The phycocyanin content in the cyanobacteria Synechococcus sp. NKBG 042902 grown under green or blue light is markedly low, while that of the cells grown under red light is high [10]. The production of marennine, a blue pigment produced by the diatom Halsela ostrearia, is controlled by bluelight radiation [32]. In addition, production of micosporine-like amino acids (MAAs) and scytonemin in cyanobacteria, phytoplankton and macroalgae has been observed as a response to counteract the damaging effect of UV-radiation [11]. Therefore, the individual light regimen becomes a predominant factor in affecting the productivity of algae.

It was reported that longer wavelength $(540 \mathrm{~nm})$ may not suitable for chlorophyll and carotene synthesis but phycocyanin and PE significantly accumulated under such wavelength. The chlorophyll synthesis was suited under white light and blue light irradiation. Longer wavelengths such as green, yellow and red lights are the main light adsorbed by photosystem II to produced highest phycocyanin and phycoerythrin content in Spirulina fussiformis. This is because at higher light wavelength phycobilisome is a highly efficient system for transferring energy to PS II reaction center [15]. In addition, under red 
or pink light radiation, most of the photosynthetic energy can be diverted into new biomass due to high carbon investment efficiency [8]. In conjunction to these phenomena, cell growth and extracellular pink pigment production of Oscillatoria strain were also stimulated proportionally under pink light radiation.

In conclusion, this research provides information that high cell growth and OsPP production were obtained from cultivation of Oscillatoria strains in modified C medium and under pink light irradiation. Modified $\mathrm{C}$ medium is simple in both chemical composition and preparation than the other media. Therefore, this medium has advantage for practical application on pink pigment production of Oscillatoria strain.

\section{References}

1. S. Singh, B.N. Kate, U.C. Banerjee. An Overview Critical Rev. Biotechnol. 25, 73-95 (2005)

2. Karseno, K. Harada, K. Hirata. Biotechnol Lett. 31, 999-1003 (2009)

3. C.M. Hildith, P. Balding, R. Jenkins, A.J. Smith, , L.J. Rogers. J. Appl. Phycol. 3, 345354 (1991)

4. A.N. Glazer. J. Appl. Phycol. 6, 105-112 (1994)

5. S. Liotenberg, D. Campbell, R. Rippka, J. Houmard, N.T. de Marsac. Microbiol. 142, 611-622 (1996)

6. S. J. Repka, J. Mehtonen, L. Vaitomaa, Saari, K. Sivonen. Microbiol. Ecol., 42, 606613 (2001)

7. K.D. Kearns, M.D. Hunter. Environ. Microbiol. 2, 291-297 (2000).

8. N. Korbee, F.L. Figueroa, J. Aguilera. J. Photochem. Photobiol. B. 80, 71-78 (2005).

9. S.G. Mihova, D.I. Georgiev, K.M. Minkova, A.A. Tchernov. J. Biotechnol. 48, 251257 (1996).

10. H.Takano, T. Arai, M. Hirano, T. Matsunaga. Appl. Microbiol. Biotechnol. 43, 10141018 (1995).

11. R.P. Sinha, Klisch, M., Groniger, A., and Hader, D.P.: Ultraviolet-absorbing/screening substances in cyanobacteria, phytoplankton and macroalgae. J. Photochem. Photobiol., B, 47, 83-94 (1998).

12. Hong Seong-Joo, Lee Choul-Gyun. Biotechnol. Bioprocess Eng. 13, 491-498 (2008).

13. U. Pandey, J. Pandey. Bioresource Technol. 99, 4520-4523 (2008).

14. M.G. Battah, E.F. Shabana, I.A. Kobbia, H.M. Eladel. Ecotoxicol. Environ. Saf. 49, 235-239 (2001).

15. H.K. Madhyastha, T.M. Vatsala. Biomol. Eng. 24, 301-305 (2007). 